\title{
Zatopené kulturní a prírodní dědictví jižní Moravy
}

\section{HANA MLEJNKOVÁ}

Klíčová slova: vodní nádrže - Vranovská přehrada - Brněnská přehrada vodní dílo Nové Mlýny - zatopené obce - Bítov - Kníničky - Mušov

\section{SOUHRN}

Projekt Zatopené kulturní a prírodní dědictví jižní Moravy byl řešen ve Výzkumném ústavu vodohospodářském T. G. Masaryka, v. v. i., v letech 2013-2016. Projekt DF13P01OVV012 byl financován Programem aplikovaného výzkumu a vývoje národní a kulturní identity (NAKI) Ministerstva kultury ČR. Nejzajímavější výsledky projektu byly odborníkům i veřejnosti prezentovány formou výstavy a knihy Zatopené kulturní a prírodní dědictví jižní Moravy. Rozsáhlé rešerše, zpracovaná data a odborné závěry byly publikovány v odborných výstupech, jako jsou recenzované články [1-6], specializované mapy [7-10], články ve sbornících [11-27] a elektronické dokumenty [28-31].

Základním tématem projektu je zamyšlení nad tím, co vše zmizelo pod hladinami vodních nádrží. Toto téma je zde zobrazeno z pohledu mnoha oborů charakterizujících kulturní a prírodní dědictví, jako je historie, vodní hospodářství, hydrobiologie, hydrochemie, geografie, jakost vod a krajinná ekologie. Jsou zde zhodnoceny změny stavu společnosti, kultury, krajiny, vodních tokü, vodních ploch a jejich využivání, biotopů a dalších složek utvárejících kulturní a prírodní dědictví jižní Moravy před a po zatopení velkých území při výstavbě přehradních nádrží.

\section{O PROJEKTU}

Na začátku byl zvídavý pohled na hladiny vodních nádrží a nabízející se otázky, co tu bylo dřive..., jak vypadala původní krajina, jak se žilo místním obyvatelům, jaké biotopy se tu nacházely a jak byly oživeny, kudy tekla pưvodní řeka? Hledání odpovědí na tyto a podobné otázky a hledání jejich vzájemných souvislostí se staly základem projektu Zatopené kulturní a prírodní dědictví jižní Moravy, který byl podpořen Ministerstvem kultury ČR v letech 2013-2016. Řešitelé projektu se je vydali hledat v archivech, pamětních knihách, obecních kronikách, odborných publikacích, ve vzpomínkách pamětníků a ve fotografiích. Jako modelové lokality byla vybrána tři charakterově odlišná vodní díla na jižní Moravě - Vranovská přehrada, Brněnská přehrada a vodní dílo Nové Mlýny (obr. 1). Ve všech těchto lokalitách došlo k zatopení alespoň částečně osídlených oblastí, včetně fungujících obcí Bítov (obr. 2-4), Kníničky (obr. 5-7) a Mušov (obr. 8-10).

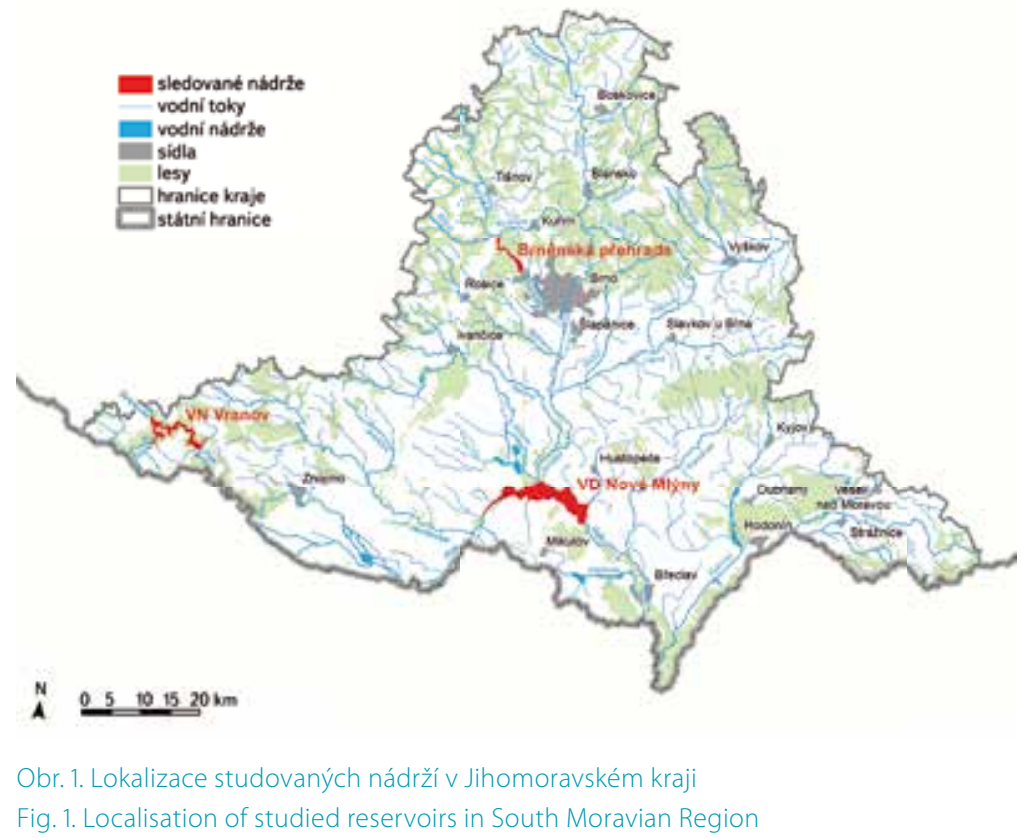

Hlavním řešitelským pracovištěm byl Výzkumný ústav vodohospodářský T. G. Masaryka, v. v. i., Praha a Brno. Partnerskými institucemi byly Ústav geoniky AV ČR, v. v. i., Výzkumný ústav Silva Taroucy pro krajinu a okrasné zahradnictví, v. v. i., Moravský zemský archiv v Brně a Povodí Moravy, s. p. Řešitelský tým byl tvořen početnou skupinou odborníků různých profesí, a to významnými historiky - prof. PhDr. Josef Unger, CSc. (Ústav antropologie PřF MU), doc. PhDr. Bohumír Smutný, Dr. (Moravský zemský archiv v Brně), PhDr. Emil Kordiovský (Státní okresní archiv Breclav se sídlem v Mikulově, dřive); biology RNDr. Zdeňka Žáková, CSc. (Biotes, Brno), doc. RNDr. Světlana Zahrádková, Ph.D., RNDr. Denisa Němejcová, Mgr. Marek Polášek, Ing. Pavel Sedláček, RNDr. Hana Mlejnková, Ph.D. (VúV TGM, v. v. i.); vodohospodáři - Ing. Arnošt Kult, Ing. Lukáš Smelík, Ph.D., Ing. Jana Uhrová, Ph.D. (VúV TGM, v. v. i.), Ing. David Veselý (Povodí Moravy, s. p.); odborníky na jakost vody a GIS - RNDr. Eva Kočková (VúV TGM, v. v. i., dříve), RNDr. Michal Pavonič (Ústav botaniky a zoologie PřF MU), Mgr. Jana Ošlejšková, Ing. Miriam Dzuráková (VúV TGM, v. v. i.) a krajinnými ekology Ing. Jan Lacina, CSc. (Ústav geoniky AV ČR, v. v. i.), Mgr. Petr Halas, Ph.D. (Ústav geoniky AV ČR, v. v. i.) a Mgr. Marek Havlíček, Ph.D. (Výzkumný ústav Silva Taroucy pro krajinu a okrasné zahradnictví, v. v. i.). 


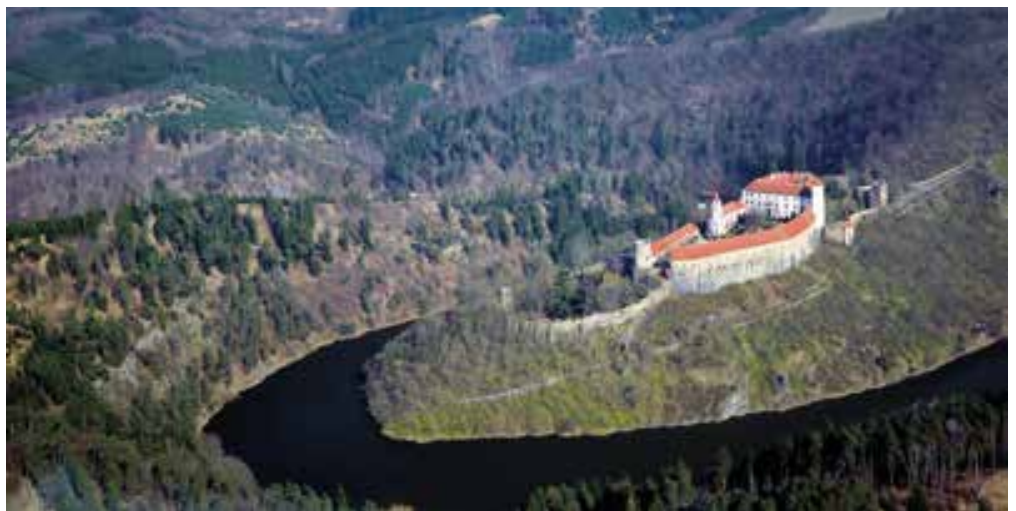

Obr. 4. Letecký pohled na Vranovskou přehradu pod hradem Bítov, kde se rozkládala původní obec Bítov (J. Zvěřina, 2015)

Fig. 4. Aerial view on the Vranov Dam, where was the former village Bítov

Uspořádání výstavy, která měla spojit mnoho na první pohled neslučitelného, a navíc formou, která by zaujala široký okruh návštěvníků, se zdálo být téměř nereálné. Díky úžasné fantazii a schopnostem Mgr. Barbory Tesařové, DiS., píli a nadšení všech řešitelů a technických pracovníků brněnské pobočky VúV TGM, v. v. i., se to povedlo nad očekávání dobře! Reakce návštěvníků a zápisy v návštěvní knize svědčí o tom, že tato práce měla smysl... dojala nejen občany ze zaplavených obcí a jejich potomky, kteři byli velmi vděční za obnovení vzpomínek na místa, kam už se dnes nemohou podívat, ale zaujala i mnoho dalších návštěvníků, kterým nabídnuté téma ukázalo dosud neznámé pohledy na vodní svět kolem nás (obr. 11).

Výstava se konala od května do června 2016 v Moravském zemském archivu v Brně. Část výstavy byla následně vystavena v budově Ministerstva životního prostředí v Praze, výstavní panely jsou trvale umístěny ve Vúv TGM, v. v. i., $\checkmark$ Praze. Průvodcem výstavou byl černobílý tištěný a rozsáhlý barevný elektronický katalog výstavy, který je uložen na webu projektu.

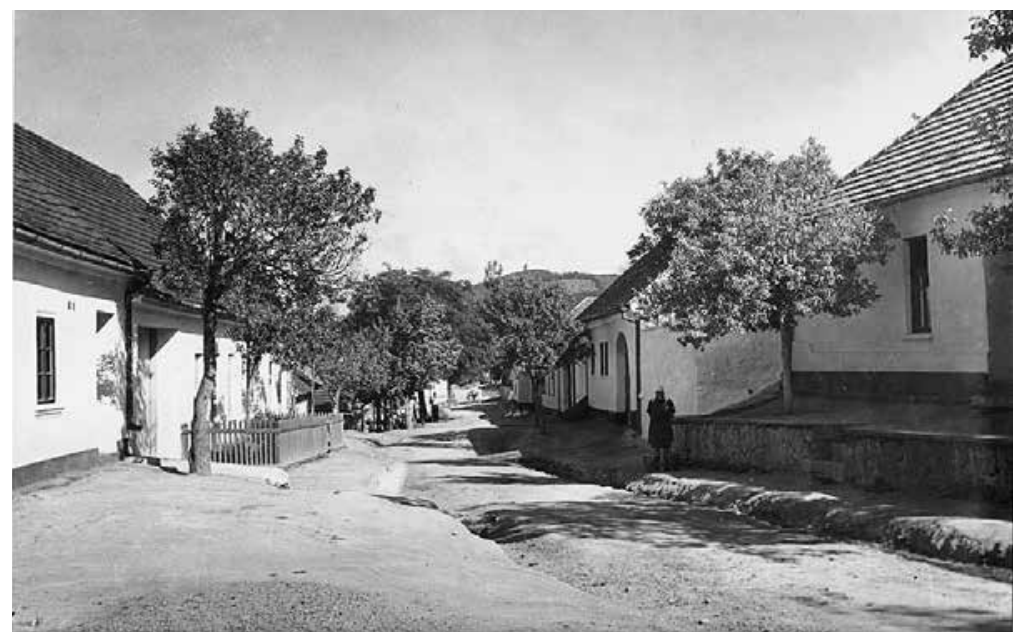

Obr. 6. Ulice ve starých Kníničkách (Archiv města Brna, A 34)

Fig. 6. Streets in old Kníničky

V lednu 2017 byla vydána populárně-vědecká publikace s názvem Zatopené kulturní a prírodní dědictví jižní Moravy (obr. 12). Kniha není určena k prodeji, je distribuována do státních a regionálních, veřejných a institucionálních knihoven, odborníkům a veřejnosti, zejména $v$ oblastech zájmových lokalit projektu. Kniha byla předána pamětníkům ze zatopených obcí, obecním úřadům v zájmových oblastech, regionálním muzeím a archivům, odborným pracovníkům ve státní správě, vč. ministerstev, a dalším zájemcům. Kniha v pdf formátu je trvale veřejně př́stupná na webových stránkách projektu: http://heis.vuv.cz/ projekty/zatopene-dedictvi.

Neplánovaným završením naší práce byla nabídka Moravského zemského archivu v Brně na založení samostatného archivního fondu s názvem Zatopené kulturní a prírodní dědictví jižní Moravy, kde budou navždy - systematicky, dohledatelně, společně - uloženy materiály shromážděné v průběhu projektu.

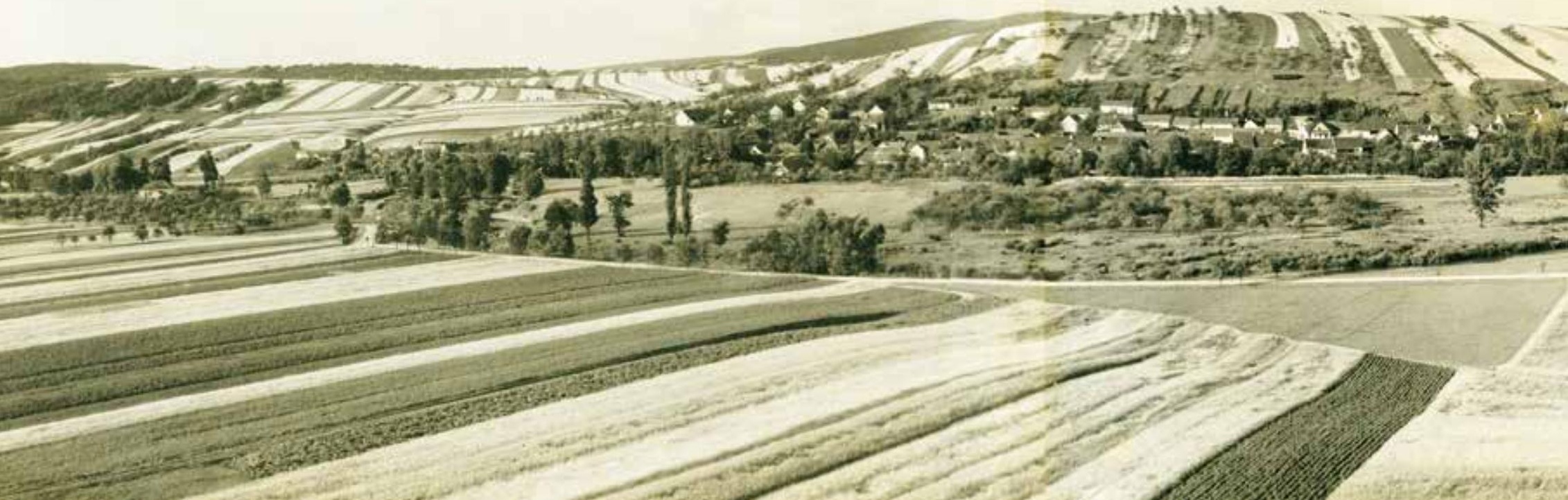




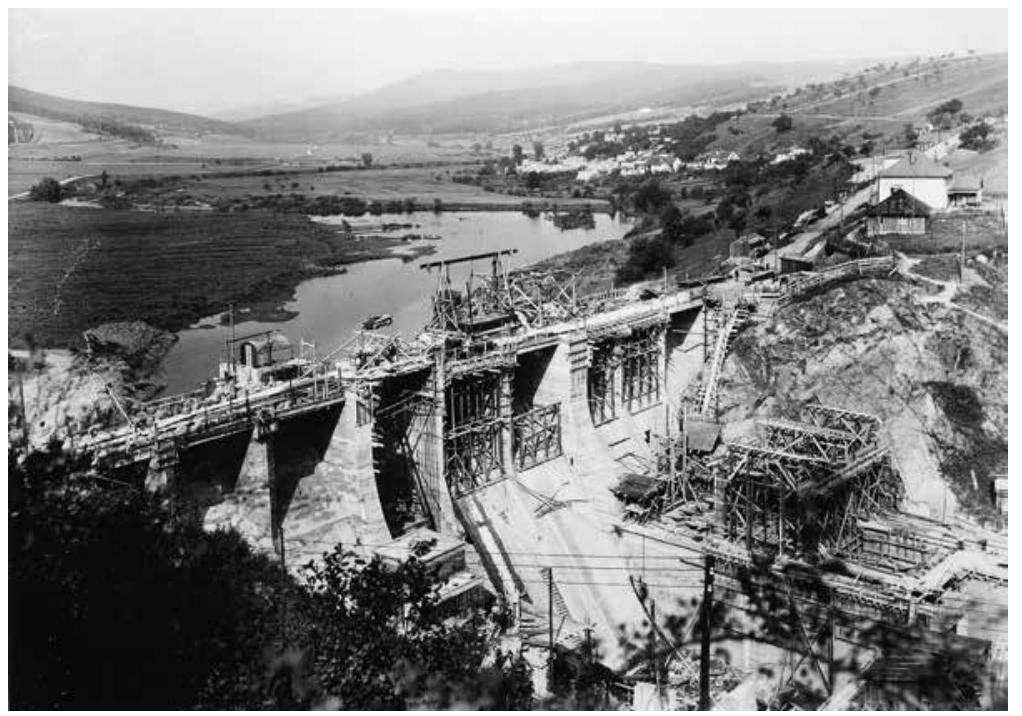

Obr. 7. Stavba hráze Kníničské přehrady, v pozadí zatopená obec Kníničky, 1939 (archiv MČ Brno-Kníničky/Z. Čižmář)

Fig. 7. Construction of the Kníničky Dam, in the background flooded village Kníničky, 1939

Dalším typem výstupů projektu jsou edukační programy Procházka starým Bítovem a Jak se žilo v Bítově a Kníničkách, než zmizely pod hladinami přehradních nádrží? (obr. 13), které byly vytvořeny za účelem informovat o historii zatopených obcí a životě v nich, určené prioritně pro žáky základních škol, ale díky poutavým a jedinečným informacím mohou zaujmout všechny generace. Oba edukační programy jsou k dispozici na webových stránkách projektu.

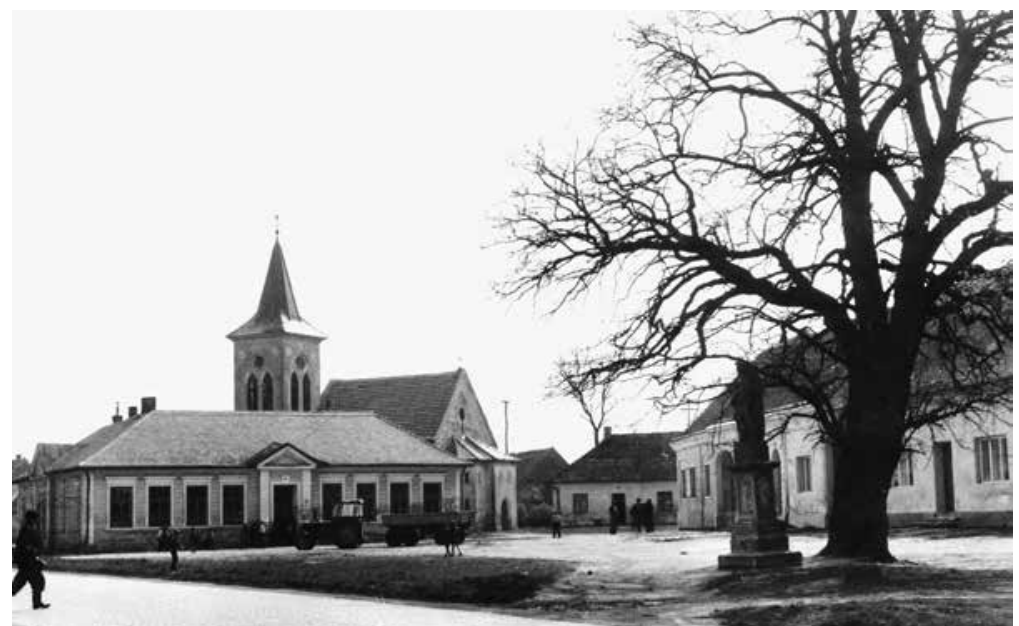

Obr. 8. Náměstí s kostelem sv. Leonarda v Mušově (Z. Zemánková)

Fig. 8. The square with St. Leonard Church in Mušov

\section{O KNIZE}

Změny v krajině, zpưsobené stavbami vodních děl, mají zcela zásadní vliv na její další charakter a vývoj. Zatopení území kompletně mění charakter krajiny, způsob života a je často příčinou nenávratné ztráty kulturního a prírodního dědictví. Nové podmínky, které se po napuštění nádrží v krajině vytváří, však nabízí nové, jiné možnosti jejího využívání a vnímání. Negativní pocity nenávratných ztrát se při navykání na novou neznámou tvár̆ krajiny pomalu mění ve zvědavé pozorování a sžívání se s tak velkou změnou. Vodní živel zaujímá své nové místo, mění se vegetace a fauna, vznikají nové biotopy, lidé se učí využívat nové podmínky a vnímat obměněnou krajinu. Smutek ze ztrát zmírňuje čas, na nepř́ijemné se zapomíná, očekává se nové, jiné... Život jde dál. Takové pocity

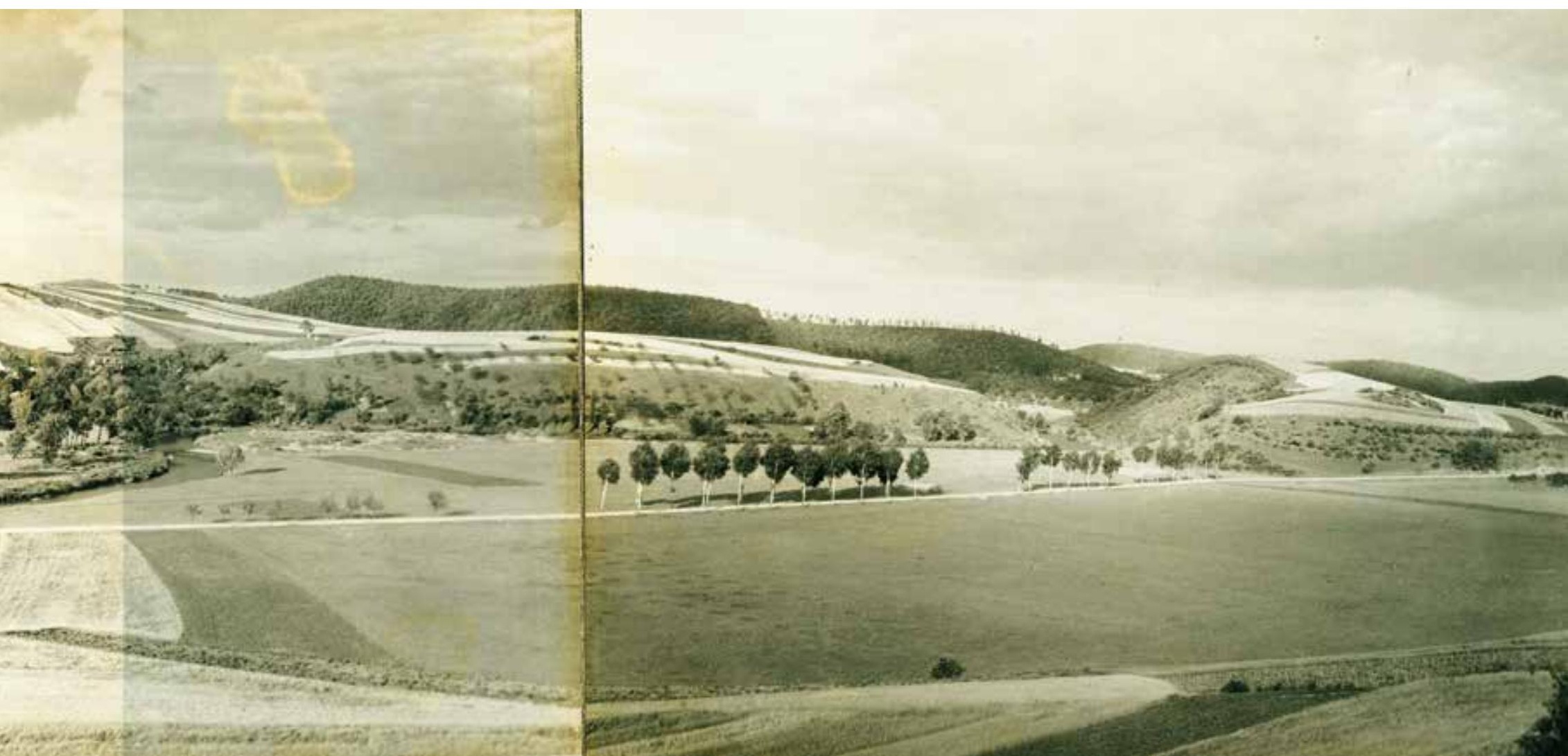




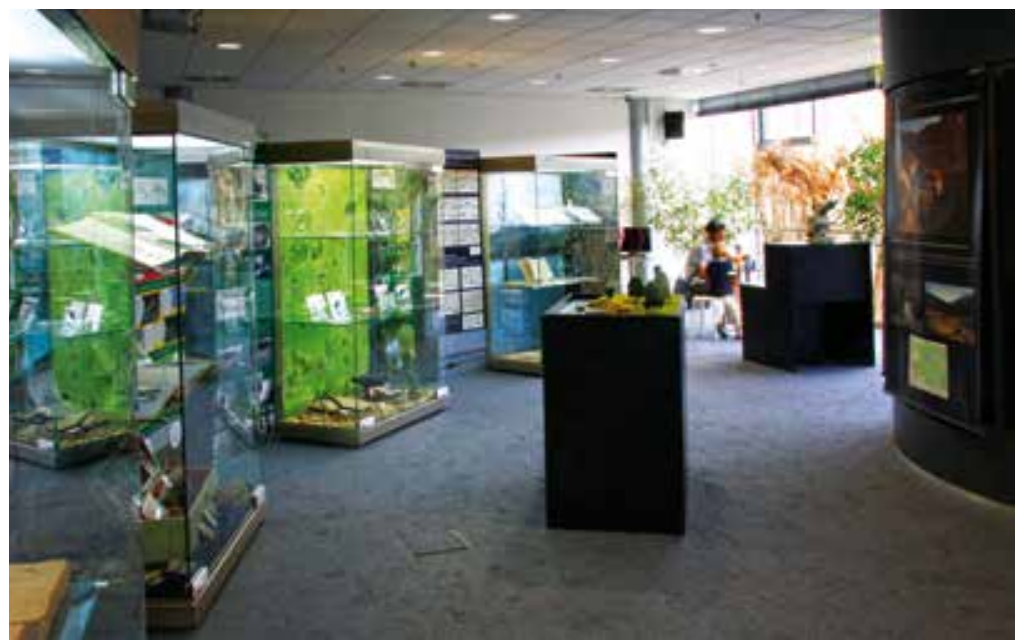

Obr. 11. Výstava Zatopené kulturní a prírodní dědictví jižní Moravy v Moravském zemském archivu v Brně (B. Tesařová, 2016)

Fig. 11. Exhibition Submerged cultural and natural heritage of South Moravia in the Moravian Regional Archives in Brno

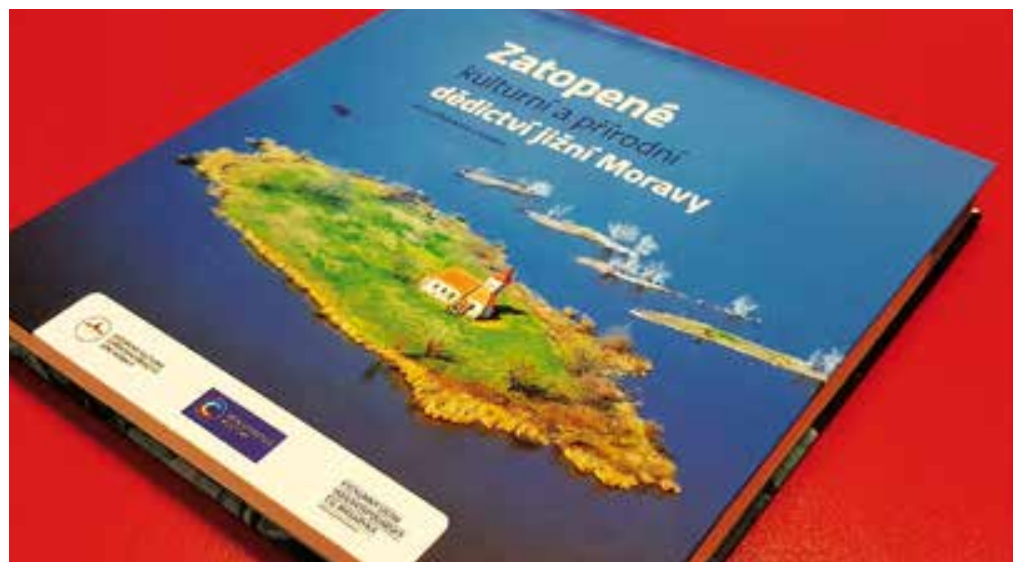

Obr. 12. Kniha Zatopené kulturní a přírodní dědictví jižní Moravy (M. Žák, 2016)

Fig. 12. Book Submerged cultural and natural heritage of South Moravia

až po výstavbě nádrží. Velmi obdobným způsobem reagovala i společenstva vodních a bažinných rostlin. K jedinečným patří kapitola věnovaná terénním biologickým stanicím, které byly v minulosti umístěny poblíz dnešní Vranovské přehrady a vodního díla Nové Mlýny. V kapitole jsou pečlivě citovány všechny prírodovědné práce věnované výzkumům v oblastech dnes zatopených vodními nádržemi. Pozornost je věnována také změnám jakosti vody $v$ tocích v souvislosti s výstavbou nádrží a vývoji zdrojů znečištění v důsledku změn využívání vodních toků. Velmi zajímavé je zpracování problematiky z pohledu krajinných ekologů, které je zaměřeno na prírodní úkazy v okolí Brněnské přehrady a vegetaci aluviálních luk jižní Moravy. Nápaditým způsobem je představeno údolí Dyje v oblasti dnešní Vranovské přehrady, kde autoři porovnávají současnou krajinu s díly malíru krajinářu 19. a 20. století. Jedinečná krajina vodního díla Nové Mlýny je také často vzpomínána v literatuře, výtvarném umění, fotografiích a ve filmech. Zatopením území se významně a viditelně změni ráz krajiny a její využívání, což bylo podrobně zpracováno s využitím dostupných historických map. Prostor je věnován i problematice povodňového ohrožení, které hrálo významnou roli nejen při rozhodování o výstavbě nádrží, ale dlouhodobě ovlivňovalo život obyvatel pravidelně zaplavovaných obcí Bítov, Kníničky a Mušov.

\section{Procházka starým Bítovem}

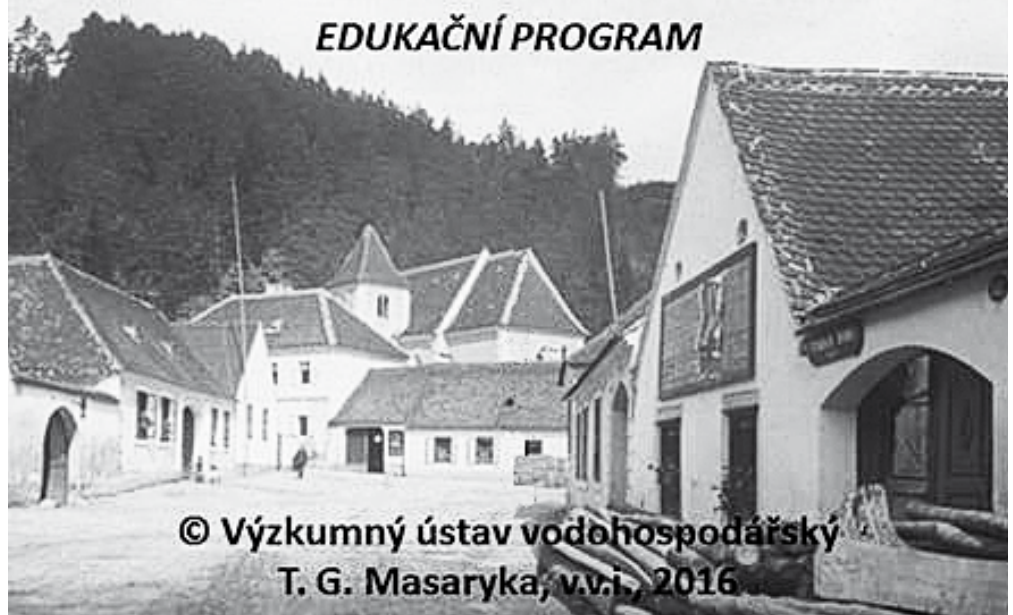

\section{Jak se žilo v Bítově a Kníničkách}

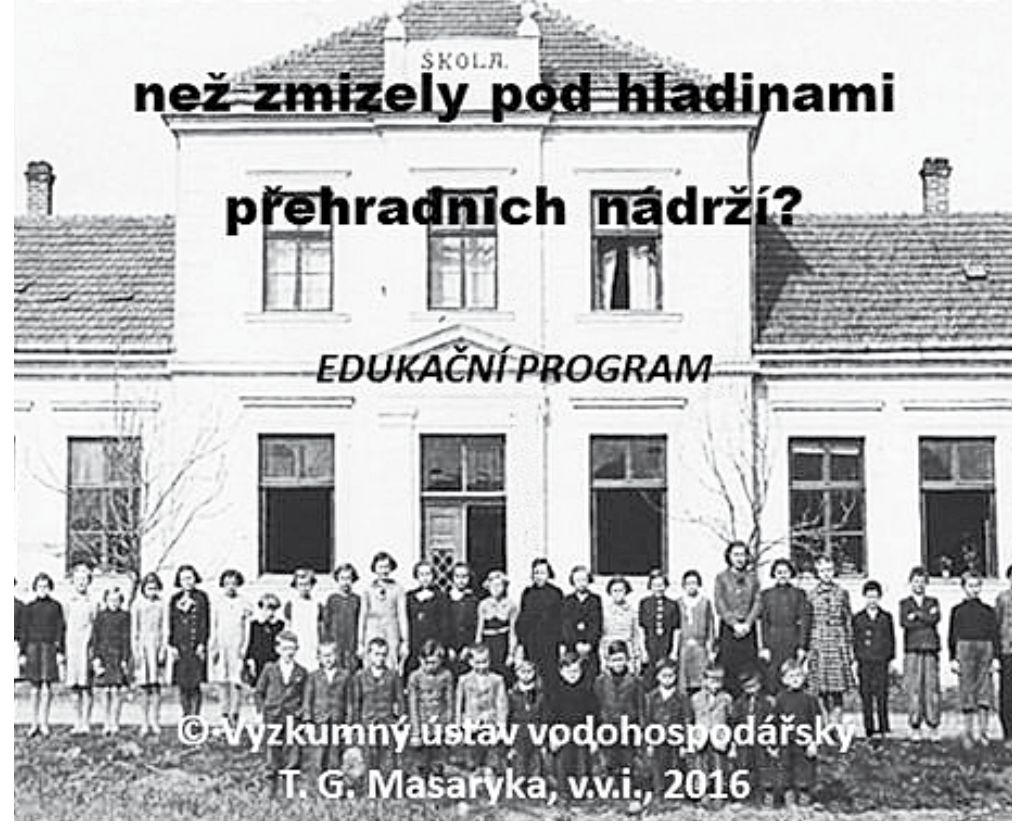

Obr. 13. Edukační programy

Fig. 13. Education programs

\section{Poděkování}

Za umožnění realizace velmi zajímavého projektu Zatopené kulturní a prírodní dědictví jižní Moravy v letech 2013-2016 a možnost vytvoření úspěšných výstupů rešitelé děkuji Programu aplikovaného výzkumu a vývoje národní a kulturní identity (NAKI) Ministerstva kultury ČR (DF13P01OVV012). 


\section{Literatura}

[1] UNGER, J. Kostel sv. Linharta v Mušově, Jižní Morava 2014, roč. 50, sv. 53, s. 217-256, ISSN 0449-0436 [2] MLEJNKOVÁ, H. Zatopené kulturní a prírodni dědictví jižni Moravy, Jižní Morava 2014, roč. 50, sv. 53, s. 215-216,ISSN 0449-0436

[3] HAVLIČEK, M., HALAS, P., LACINA, J. a MLEJNKOVÁ, H. Změny využití krajiny u jihomoravských vodních nádrží. Acta Pruhoniciana, 2014, roč. 2014, č. 108, s. 25-35. ISSN 1805-921X.

[4] KORDIOVSKÝ, E. Válečné škody z let 1938-1945 v oblasti Novomlýnských nádrží, Jižní Morava 2014, roč. 50, sv. 53, s. 257-284, ISSN 0449-0436.

[5] MLEJNKOVÁ, H. Zatopené kulturní a přírodní dědictví jižní Moravy. In: Rádková V. (ed.) a Bojková J (ed.) XVII. konference České limnologické společnosti a Slovenskej limnologickej spoločnosti "Voda - věc veřejná": Sborník přispěvků. Brno: Masarykova universita, 2015, s. 110. ISBN 978-80-210-7874-1.

[6] SMUTNÝ, B. Obce zmizelé ve 20. století pod vodní hladinou a jejich stav koncem feudalismu (Bítov, Kníničky, Mušov), Jižní Morava, 2015, roč. 51, s. 329-345. ISSN 0449-0436, ISBN 978-80-86931-85-2.

[7] MLEJNKOVÁ, H., HAVLIČEKK, M., KONVIT, I., PAVLÍK, F. a HALAS, P. Změny využití krajiny vzázemívodní nádrže Vranov. 2016, specializovaná mapa. Ministerstvo zemědělství ČR. Datum schválení: 31. 8. 2016.

[8] MLEJNKOVÁ, H., HAVLIČEK, M., KONVIT, I., PAVLÍK, F. a HALAS, P. Změny využití krajiny v zázemí vodního díla Brno. 2016, specializovaná mapa. Ministerstvo zemědělství ČR. Datum schválení: 31. 8. 2016.

[9] MLEJNKOVÁ, H., HAVLÍČEK, M., KONVIT, I., PAVLÍK, F. a HALAS, P. Změnyvyužitíkrajiny vzázemívodního díla Nové Mlýny. 2016, specializovaná mapa. Ministerstvo zemědělství ČR. Datum schválení: 31. 8. 2016.

[10] MLEJNKOVÁ, H., UHROVÁ, J., HAVLÍČEK, M., KONVIT, I., PAVLÍK, F. a HALAS, P. Vliv změny využití krajiny na ohroženost půdy vodni erozí v zázemí vodního díla Nové Mlýny. 2016, specializovaná mapa. Ministerstvo zemědělství ČR. Datum schválení: 31. 8. 2016.

[11] MLEJNKOVÁ, H. Zatopené kulturní a prírodní dědictví jižní Moravy - projekt programu NAKI. In: Štiková, K., Pithart, D. Říční krajina 10. Brno, 15. 10. 2014. Brno: Koalice pro řeky, 2014, s. 68-73. ISBN 978-80-260-7099-3.

[12] KOČKOVÁ, E. a OŠLEJŠKOVÁ, J. Vývoj vlivu zdrojů znečištění na kvalitu vody na jižní Moravě. In: Štiková, K., Pithart, D. Říční krajina 10. Brno, 15. 10. 2014. Brno: Koalice pro řeky, 2014, s. 43-48. ISBN 978-80-260-7099-3.

[13] HAVLIIČEK, M., PAVLÍK, F. a KONVIT, I. Změny využití krajiny u jihomoravských vodních nádrží a jejich vliv na vodní erozi. In: Štiková, K., Pithart, D. Řiční krajina 10. Brno, 15. 10. 2014. Brno: Koalice pro reky, 2014, s. 22-27. ISBN 978-80-260-7099-3.

[14] PAVONIČ, M. a KOČKOVÁ, E. Dlouhodobé ovlivnění chemické a mikrobiologické kvality vody vodním dílem Nové Mlýny. In: Štiková, K., Pithart, D. Řičníkrajina 10. Brno, 15. 10. 2014. Brno: Koalice pro reky, 2014, s. 74-84. ISBN 978-80-260-7099-3.

[15] POLÁŠEK, M., ZAHRÁDKOVÁ, S. a NËMEJCOVÁ, D. Změna struktury biotopů po výstavbě Novomlýnských nádržía důsledky pro modelové druhy vodních bezobratlých. In: Štiková, K, Pithart, D. Řičníkrajina 10. Brno, 15. 10. 2014. Brno: Koalice pro řeky, 2014, s. 92-93. ISBN 978-80-260-7099-3.

[16] SMELÍK, L. a DZURÁKOVÁ, M. Problematika podkladových materiálů pro stanovení původní kapacity koryta zatopeného nádrží. In: Štiková, K., Pithart, D. Říční krajina 10. Brno, 15. 10. 2014. Brno: Koalice pro řeky, 2014, s. 102-107. ISBN 978-80-260-7099-3.

[17] ŽÁKOVÁ, Z. Změny rostlinných společenstev v řece Dyji po vybudování vodních nádrží Vranov a Nové Mlýny. In: Štiková, K., Pithart, D. Říčníkrajina 10. Brno, 15. 10. 2014. Brno: Koalice pro řeky, 2014, s. 128-134. ISBN 978-80-260-7099-3.

[18] MLEJNKOVÁ, H. Zatopené kulturní a prírodní dědictví jižní Moravy - projekt programu NAKL. In: Mgr. Miroslav Svoboda, Ph.D. XXXII. Mikulovské sympozium „Voda v dějinách Moravy“. Člověk a voda $\checkmark$ dějinách: život - prostředí - technika - každodennost - rituály. Mikulov, 22. 10. 2014. Muzejní a vlastivědná společnost v Brně, 2015, s. 337-345. ISBN 978-80-86931-99-4.

[19] KORDIOVSKÝ, E. Válečné škody na vodních tocích okresu Břeclav v letech 1938-1945. In: Mgr. Miroslav Svoboda, Ph.D. XXXII. Mikulovské sympozium voda v dějinách Moravy". Člověk a voda $\checkmark$ dějinách: život - prostředí - technika - každodennost - rituály. Mikulov, 22. 10. 2014. Muzejní a vlastivědná společnost v Brně, 2015, s. 300-325. ISBN 978-80-86931-99-4.

[20] UNGER, J. Voda na soutoku Jihlavy, Svratky a Dyje v lichtenštejnském urbáři z roku 1414. In: Mgr. Miroslav Svoboda, Ph.D. XXXII. Mikulovské sympozium "Voda v dějinách Moravy". Člověk a voda v dějinách: život - prostředí - technika - každodennost - rituály. Mikulov, 22. 10. 2014. Muzejní a vlastivědná společnost v Brně, 2015, s. 32-36. ISBN 978-80-86931-99-4.

[21] VESELÝ, D. Tradice hospodaření v nivě - hledání zahraniční analogie. In: Mgr. Miroslav Svoboda, Ph.D. XXXII. Mikulovské sympozium „Vodav dějinách Moravy”. Člověk a voda v dějinách: život - prostředítechnika - každodennost - rituály. Mikulov, 22. 10. 2014. Muzejní a vlastivědná společnost v Brně, 2015, s. 416-426. ISBN 978-80-86931-99-4.

[22] KULT, A. Měl Tiberius Claudius Nero v plánu v rámci chystaného útoku směrovaného proti markomanskému králi Marobudovi v roce 6 n l l využí k zajištění zásobování svých legií římské ruíční lodě na řece Moravě? In: Mgr. Miroslav Svoboda, Ph.D. XXXII. Mikulovské sympozium „Voda v dějinách Moravy". Člověk a voda v dějinách: život - prostředí - technika - každodennost - rituály. Mikulov, 22. 10. 2014. Muzejní a vlastivědná společnost v Brně, 2015, s. 9-24. ISBN 978-80-86931-99-4.

[23] KONVIT, I. Vývoj vodních toků a vodních ploch v zatopených územích jižní Moravy. In: Mgr. Miroslav Svoboda, Ph.D. XXXII. Mikulovské sympozium "Voda v dějinách Moravy". Člověk a voda v dějinách: život - prostředí - technika - každodennost - rituály. Mikulov, 22. 10. 2014. Muzejní a vlastivědná společnost v Brně, 2015, s. 346-361. ISBN 978-80-86931-99-4.
[24] HAVLIĆEKE, M. PAVLIIK, F. a HALAS, P. Vývoj využití krajiny u jihomoravských vodních nádrží a jejich zázemí. In: Mgr. Miroslav Svoboda, Ph.D. XXXII. Mikulovské sympozium „Voda v dějinách Moravy". Člověk a voda v dějinách: život - prostředí - technika - každodennost - rituály. Mikulov, 22. 10. 2014. Muzejni a vlastivědná společnost v Brně, 2015, s. 362-378. ISBN 978-80-86931-99-4

[25] ŽÁKOVÁ, Z. Jak ovlivnilo vybudování nádrží Vranov nad Dyjí a Nové Mlýny rostlinná společenstva v řce Dyjii? In: Mgr. Miroslav Svoboda, Ph.D XXXII. Mikulovské sympozium Voda v dějinách Moravy". Člověk a voda v dějinách: život - prostředí - technika - každodennost - rituály. Mikulov, 22. 10. 2014. Muzejní a vlastivědná společnost v Brně, 2015, s. 390-406. ISBN 978-80-86931-99-4.

[26] NĚMEJCOVÁ, D., ZAHRÁDKOVÁ, S. a POLÁŠEK, M. Nenápadný svět vodních bezobratlých obraz vývoje krajiny. In: Mgr. Miroslav Svoboda, Ph.D. XXXII. Mikulovské sympozium „Voda v dějinách Moravy". Člověk a voda v dějinách: život - prostředí - technika - každodennost - rituály. Mikulov, 22. 10. 2014. Muzejní a vlastivědná společnost v Brně, 2015, s. 407-415. ISBN 978-80-86931-99-4.

[27] SMELÍK, L.a DZURÁKOVÁ, M. Stanovení orientační kapacity koryt před zatopením jihomoravským nádržemi dle historických podkladů. In: Svoboda, M. XXXII. Mikulovské sympozium „Voda v dějinách Moravy". Člověk a voda v dějinách: život - prostředí - technika - každodennost - rituály. Mikulov 22. 10. 2014. Muzejní a vlastivědná společnost v Brně, 2015, s. 379-390. ISBN 978-80-86931-99-4.

[28] SMELÍK, L. a kol. Edukační program „Procházka starým Bítovem“" [on-line]. VúV TGM, v. v. i., 2016, 15. 11. 2016. Dostupné z: http://heis.vuv.cz/projekty/zatopene-dedictvi

[29] NËMEJCOVÁ, D. a kol. Edukační program „Jak se žilo v Bítově a Kníničkách nežzmizely pod hladinam prehradnich nádrží?" [on-line]. vúv TGM, v. v. i., 2016, 15. 11. 2016. Dostupné z: http://heis.vuv.cz/ projekty/zatopene-dedictvi

[30] MLEJNKOVÁ, H. a kol. Databáze Zatopené kulturní a prírodní dědictví jižni Moravy [on-line]. VúV TGM, v. v. i., 2016, 18. 10. 2016. Dostupné z: http://heis.vuv.cz/data/webmap/datovesady/projekty/ zatopenededictvi/dtb.asp

[31] MLEJNKOVÁ, H. a kol. Katalog výstavy Zatopené kulturní a př́rodní dědictví jižní Moravy [on-line]. VúV TGM, v. v. i., 2016, 2. 5. 2016. Dostupné z: http://heis.vuv.cz/projekty/zatopene-dedictvi

\section{Autor}

RNDr. Hana Mlejnková, Ph.D.

凶hana.mlejnkova@vuv.cz

Výzkumný ústav vodohospodářský T. G. Masaryka, v. v. i. 


\section{SUBMERGED CULTURAL AND NATURAL HERITAGE OF SOUTH MORAVIA}

MLEJNKOVA, $\mathrm{H}$.

TGM Water Research Institute, p. r. i.

Keywords: water reservoirs - Vranov Dam - Brno Dam - system of reservoirs Nové Mlýny - submerged villages - Bítov - Kníničky - Mušov

The project "Submerged cultural and natural heritage of South Moravia" was solved in the T. G. Masaryk Water Research Institute, p. r. i., in 2013-2016. Project DF13P01OVV012 was founded by the Programme of applied research and development of national and cultural identity (NAKI) supported by Ministry of Culture of the Czech Republic. The most interesting results of the project were presented to professionals and the general public at the exhibition and in the book Zatopené kulturní a prírodní dědictví jižní Moravy. Extensive searches, processed data and expert's results were published in professional outputs as rewieved articles [1-6], specialised maps [7-10], articles in collections [11-27] and electronical documents [28-31].

The main subject of the project is the thought about what all was lost beneath the water of reservoirs. This topic is viewed from the perspective of many disciplines, characterizing the cultural and natural heritage such as history, water management, hydrobiology, water chemistry, geography, water quality and landscape ecology. There are evaluated changes in the society, culture, landscapes, rivers, water bodies and their use; habitats and other parts forming the cultural and natural heritage of South Moravia before and after flooding of large areas due to the construction of dams. Three characteristically different water bodies in South Moravia - Vranov Dam, Brno Dam and the system of reservoirs Nové Mlýny were chosen as the model localities. In all these localities populated areas, including villages Mušov, Bítov and Kníničky, were submerged. 